\title{
PASTOR COMO HIPERCONVERTIDO: UMA ETNOGRAFIA DA CONSTITUIÇÃO DO LÍDER PENTECOSTAL
}

\author{
Cleonardo Mauricio-Junior \\ Universidade Federal de Pernambuco (UFPE) \\ Recife, PE - Brasil \\ Orcid: https://orcid.org/0000-0002-5267-4395
}

\section{Introdução}

"Falar é crer." Assim Susan Harding intitula o primeiro capítulo de The Book of Jerry Falwell (2000), obra que já pode ser considerada incontornável para o tema da conversão entre os evangélicos. $\mathrm{O}$ argumento de Harding é o de que a conversão diz respeito ao processo de aquisição de uma linguagem religiosa específica (Harding 2000:34). Entre seus sujeitos de pesquisa, os batistas fundamentalistas americanos, converter-se significa passar de ouvinte a falante, as quais seriam, respectivamente, as marcas do perdido (unsaved) e do salvo (saved). Seguindo Harding, meu objetivo neste artigo é apresentar a conversão ao pentecostalismo como a habilidade de se construir uma narrativa de si mesmo - sempre em andamento - baseada em uma ruptura com um eu anterior nos moldes do que já vêm trabalhando os autores filiados à agenda teórico-metodológica da Antropologia do Cristianismo (Robbins 2003; Cannell 2006; Bialecki et al. 2008; Campos \& Reesink 2014; Mauricio Junior 2014). Reforço o "sempre em andamento", uma vez que há a necessidade contínua e renovada de se prestar contas da inteligibilidade e adequação dessa narrativa a fim de que ela seja autorizada por uma comunidade de sentido (Coleman 2003). A conversão aqui será entendida, portanto, como um processo contínuo (como na noção de continuous 
conversion, Coleman 2003), no qual se empreende uma transformação de si baseada fortemente em uma reforma da linguagem a partir da absorção de uma ideologia da linguagem específica (Keane 2007). Essa transformação de si exige sempre o alcance de um outro, próximo ou distante (irmão de fé ou não crente) para que este seja também transformado (Coleman 2000, 2018; Mauricio Junior \& Campos 2018).

Mais especificamente, meu propósito é dar conta de um caso particular na trajetória da conversão ao pentecostalismo: aquele em que um sujeito é elevado acima de seus pares no que diz respeito ao domínio da construção e da performance da narrativa tornando-se pastor pentecostal. Sendo assim, considero o pastor pentecostal como hiperconvertido: se todo convertido precisa estar apto a construir e compartilhar, ou compartilhar enquanto constrói, determinada narrativa de si (Coleman 2006; Campos \& Mauricio Junior 2012), os hiperconvertidos são separados para funções específicas na comunidade pentecostal (principalmente a de pastor) porque tornaramse os virtuoses da ideologia da linguagem pentecostal. São os mestres da narrativa.

São duas as condições essenciais para a confirmação de um fiel como apto ao pastorado pentecostal e que se configuram como a busca do domínio de performances narrativas: o primeiro é a construção do relato do chamado, na qual o líder pentecostal mostra que foi escolhido por Deus para exercer um ministério específico no mundo. Geralmente o vocacionado conta histórias de encontros extraordinários com Deus ou com irmãos de fé que servem para legitimar o propósito de se lançar à carreira de pastor. O segundo consiste na necessidade - e obrigação - que os vocacionados têm de serem "usados por Deus". Isso acontece principalmente na ocasião da prédica direcionada ao restante dos fiéis. Sendo assim, ser chamado por Deus e ser usado por Deus são premissas indispensáveis a todo líder pentecostal, cuja estruturas, processo de aprendizado e execução das performances eu apresentarei neste trabalho.

As análises aqui apresentadas baseiam-se em trabalho de campo conduzido primeiramente na Escola de Líderes da Associação Vitória em Cristo (Eslavec) ${ }^{1}$ realizada na cidade de Águas de Lindoia, em São Paulo, em dezembro de 2012.32A Eslavec é conduzida pelo pastor Silas Malafaia, ${ }^{3}$ líder da Associação Vitória em Cristo ${ }^{4}$ e pastor presidente da Assembleia de Deus Vitória em Cristo (Advec), ${ }^{5}$ cuja sede se encontra na cidade do Rio de Janeiro, no bairro da Penha. Após o congresso, acompanhei jovens recém-ordenados pastores e candidatos ao pastorado que haviam participado da Escola de Líderes e faziam parte de filiais da Advec no Recife (PE), nos bairros de Boa Viagem, zona sul da capital e Cordeiro, bairro periférico na zona oeste. Também acompanhei jovens pastores pentecostais de outras denominações: frequentei as igrejas Vida e Paz, na cidade de Camaragibe (PE), e a Igreja Batista Missionária Palavra Viva, ${ }^{6}$ no bairro da Várzea, zona oeste do Recife, na tentativa de estender a compreensão do fenômeno aqui estudado para o campo pentecostal em geral. São esses jovens ${ }^{7}$ que decidiram enveredar pela carreira de pastor pentecostal que apresentarei aqui, chamando-os ora de líderes, ${ }^{8}$ ora de vocacionados, a fim de iluminar o processo de hiperconversão. 
As performances narrativas sobre as quais me debruçarei neste trabalho, como disse acima, compõem o aprendizado de uma ideologia da linguagem que visa a transformação do sujeito. Apresentarei agora os conceitos de ideologia da linguagem (Keane 2002, 2007) e da sinceridade (Keane 2002; Mafra 2014) que ajudam a iluminar como se dá essa reforma da linguagem. Não obstante, as dimensões da hiperconversão que vão além da linguagem não podem ser ignoradas. Trabalharei, então, na sequência, conceitos como o de ideologia semiótica (Keane 2007, 2018) e de experiência (Turner 2005; Bruner 1986) que irão me ajudar a abordar esse fenômeno em sua complexidade. Depois, baseando-me nos dados de minha etnografia entre os candidatos a pastor pentecostal, irei delinear a estrutura das performances narrativas do chamado e da prédica, mostrando como os vocacionados alcançam a legitimidade de terem sido chamados por Deus e de serem usados por Deus. Os depoimentos dos vocacionados a respeito de como entendem terem sido chamados por Deus para serem pastores, a prédica de um pastor americano, principal atração da escola de líderes da qual participei, bem como as reações dos vocacionados a essa e às suas próprias performances servirão de base para minha análise.

\section{Linguagem, materialidade e experiência}

Por ideologia da linguagem entende-se as convicções das pessoas a respeito da linguagem e de como ela funciona (Keane 2007). Mais especificamente, essas ideologias "são conjuntos de crenças articuladas por seus usuários na forma de uma racionalização ou justificativa do uso e da estrutura percebida da linguagem" (Keane 2007:16). Sendo assim, há uma dimensão de reflexividade quando se fala de ideologia da linguagem, presente na própria noção de ideologia usada por Keane, que não diz respeito à ideia de falsa consciência, mas enfatiza os efeitos produtivos da consciência reflexiva, ainda que esta seja sempre parcial (2007:17).

Para Webb Keane (2002), o principal elemento da conversão como o processo de tornar-se versado na ideologia da linguagem protestante é o ideal normativo da sinceridade. Ser sincero, diz Keane, significa "proferir palavras que serão interpretadas principalmente como uma expressão de crenças ou intenções subjacentes" (Keane 2002:74). Haveria, na ideologia da linguagem protestante, um isomorfismo entre as palavras proferidas e os estados interiores, estando "tanto os pensamentos quanto as palavras sobre o total controle do eu falante" (idem:75). Alguns autores, como Simon Coleman (2006), indicam que a ideologia da linguagem pentecostal, por sua vez, apresentaria um contraste em relação ao ideal normativo da fala sincera, uma vez que as narrativas eficazes e eticamente carregadas, baseadas nos dons e carismas, precisam confirmar sua origem em uma potência fora do indivíduo, como o Espírito Santo. Outros autores (Bialecki 2011; Mafra 2014; Reinhardt 2016) abrem a possibilidade para um repertório de diversas ideologias da linguagem dentro da mesma tradição pentecostal, estejam elas em conflito ou se retroalimentando. 
Jon Bialecki (2011) parece ser o autor que traz a solução mais conciliatória nesse sentido. As ideologias linguísticas no cristianismo, para ele, seriam principalmente duas: a forma centrípeta, mais próxima da ideologia da sinceridade protestante, a qual, além de restringir leituras alegóricas da bíblia, enfatiza a agência do sujeito, desvalorizando, ou mesmo reprimindo, fontes outras da linguagem presentes em qualquer ato comunicativo. A forma centrífuga, por sua vez, coloca uma ênfase nas leituras alegóricas e figurativas e destaca a origem externa da linguagem. Essa seria a ideologia linguística própria das formas carismáticas do cristianismo. No entanto, Bialecki aponta para o fato de que essas formas linguísticas estariam ligadas uma à outra, convivendo no seio das mesmas tradições. Os aspectos centrípetos e centrífugos da linguagem estariam, então, "acorrentados um ao outro", ou convivendo em uma "relação parasítica" (Bialecki 2011:684). Assim, assumo essa retroalimentação entre formas de linguagem descrita por Bialecki, mas, mais do que determinar se esta ou aquela prática está mais próxima do aspecto centrípeto ou centrífugo da linguagem, minha intenção é mostrar que converter-se é tornar-se determinado tipo de pessoa, e uma pessoa que fala/narra, pois passou de ouvinte a falante e tem a necessidade de legitimar essa fala enquadrando-a em determinado repertório linguístico/semiótico.

Dessa forma, além do aspecto metadiscursivo, as ideologias linguísticas/semióticas apontam para o aspecto moral do discurso da conversão. Os pastores pentecostais são alvos de intenso escrutínio da comunidade, que avalia se seus líderes são "homens de Deus", "cheios da unção", enfim, "cheios do Espírito Santo". A performance da prédica, cuja execução bem-sucedida é um dos lastros da hiperconversão (o outro sendo, como veremos, o relato do chamado), consiste em colocar-se sob avaliação a fim de que se confirme a legitimidade da narrativa. Ser consagrado como mestre da narrativa é uma tarefa especialmente árdua para os pastores em início de carreira que apresentarei aqui, uma vez que a instabilidade da posição de hiperconvertido gera a necessidade de constante aperfeiçoamento da narrativa e a busca incessante da excepcionalidade das experiências.

Apesar de voltar o foco para o chamado e a prédica, ambos atos de fala, é importante dizer que não estou assumindo uma abordagem estritamente discursiva, em outras palavras, que exclui a dimensão material da hiperconversão. Antes de tudo porque, como diz Birgit Meyer (2019:105), "algum nível de materialidade é indispensável para a religião estar presente no mundo", mesmo no caso de religiões iconofóbicas e antimateriais como algumas das ramificações evangélicas, incluindo o pentecostalismo que apresentarei aqui. Desse modo, é preciso, ainda seguindo Meyer, "rematerializar o estudo da religião" uma vez que o fenômeno religioso sobre o qual me debruço lança mão da "desmaterialização", ou seja, de "uma operação semiótica que minimiza ou ignora (geralmente a própria) materialidade, colocando-a em oposição à espiritualidade e estabelecendo o antagonismo entre a religião e as coisas" (Meyer 2019: 94, 95). Apesar de tanto as performances do chamado quanto da prédica apresentarem uma estrutura relativamente fixada, como, no caso da primeira, com a obrigatoriedade de estar permeada da mitopráxis dos dramas bíblicos, essa 
fixidez, bem como a materialização e a mediação dessas performances devem ser obnubiladas. Isso em nome da construção de um sentido de extraordinariedade (Deus não opera segundo os preceitos dos homens), exclusividade (o Espírito Santo não se revela da mesma forma a ninguém) e insondabilidade da experiência (não se sabe de onde o Espírito vem, nem para onde vai). É a noção de ideologia semiótica que serve para iluminar como, apesar de assumir um papel central no caso aqui analisado, a linguagem se liga a outros domínios semióticos (Keane 2007), direcionando nossa atenção para uma variedade "de veículos de signos possíveis e as modalidades sensoriais que eles podem envolver, incluindo som, cheiro, tato, movimento muscular, dor, afeto e outros fenômenos somáticos" (Keane 2018:65). O que Birgit Meyer chama de formas sensoriais (Meyer 2018) ilumina os mecanismos da passagem da transcendência à imanência na prática dos fiéis. A ideologia da linguagem, enfim, compõe uma economia representacional que a ideologia semiótica organiza normativamente, definindo o que é material e, em contrapartida, o imaterial, estabelecendo ainda a hierarquia entre ambos bem como entre as demais formas de significação envolvidas.

A dimensão da experiência da hiperconversão, diga-se, da constituição do pastor pentecostal também precisa ser ressaltada. Entendo experiência aqui, de acordo com Victor Turner (2005), como "um choque de prazer ou dor" que "como uma pedra no jardim de areia zen" irrompe nos interstícios do cotidiano interrompendo o movimento rotinizado e repetitivo da vida comum (Turner 2005:178). A experiência aqui evocada tem a ver com o extraordinário e acontece, no modo subjuntivo da vida, em contraposição ao modo indicativo, este sendo caracterizado por "uma expectativa invariante de causa e efeito, senso comum e racionalidade" (Turner 2005:183). E justamente por acontecerem no modo subjuntivo da vida têm um caráter "formativo e transformativo" (2005:179) do sujeito. Falar da hiperconversão como experiência nos moldes de Victor Turner implica também em considerá-la performance narrativa, uma vez que "a experiência incita a expressão". Uma experiência "é, em si mesmo, um processo que pressiona por uma expressão que a complete" (Turner 1982:13), assim "os significados obtidos às duras penas devem ser ditos, pintados, dançados, dramatizados, enfim, colocados em circulação" (Turner 2005:180). Entendo que tanto o relato do chamado quanto a prédica pentecostal são performances narrativas (Austin 1990; Bauman 1975; Turner 1982, 1988, 2005) que completam apropriadamente as experiências que passarei a apresentar.

Sigo agora para mostrar como o relato do chamado e a performance da prédica são estruturados e como esses gêneros narrativos e atos performativos operam na constituição do vocacionado ao pastorado pentecostal.

\section{Ser chamado por Deus}

Por "chamado" os pentecostais entendem aquilo pelo qual foram designados por Deus para fazerem no mundo, sua participação direta no que chamam de 
"a obra de Deus". Podem referir-se a esse chamado também como "o ministério de Deus para as suas vidas" ("Meu ministério é...", "O ministério de Deus para minha vida é..."). ${ }^{9}$ Ao ser perguntado como se deu a ocasião de seu "chamado" para pastor, o vocacionado, em geral, relata uma experiência mística que define o momento no qual foi separado, chamado por Deus para a carreira pastoral. Assim Ivan (26 anos, Advec), conta como seu chamado para ser pastor-missionário tinha ficado mais claro aos dezesseis anos:

- Claro? De que forma?

- Foi quando Deus usou uma irmã... Ela me parou na rua e disse o seguinte: - "Ivan, sabe o que Deus está me mostrando? Que você vai ser enviado, você e sua família, para o campo missionário." E aquilo ardia muito forte no meu coração desde pequeno, mas não era claro. Mas só que nesse período, entre 16 e 18 anos, quando a irmã Gorete falou que Deus iria me enviar [junto com minha família] para o campo missionário eu não estava sequer namorando...

... E o lugar que Deus me mostrava era um só, o Egito. Eu sou apaixonado pelo Egito. Eu não entendia. Hoje entendo porque desde pequeno eu era apaixonado pelas coisas do Egito. Estudei as pirâmides. Estudei a história do lugar, as dinastias dos faraós. Estudei tudo. E eu não entendia porque eu era tão apaixonado por isso. Era por causa do chamado de Deus na minha vida e eu não entendia ainda...

É possível perceber nesta conversa pelo menos dois componentes indispensáveis para que o relato do chamado seja considerado legítimo. Primeiramente o que chamo de "desejo no coração", representado pela seguinte declaração de Ivan em relação ao seu chamado: "aquilo [o desejo de seguir para o campo missionário] ardia muito forte no meu coração desde pequeno, mas não era claro." Assim como no momento em que ele conta ter demonstrado interesse desde cedo pelas coisas concernentes ao Egito, sem entender "porque era tão apaixonado por isso". A segunda etapa poderia ser confundida com o chamado em si mesmo, se não entendêssemos que se trata de um processo de construção de uma narrativa. Podemos classificar esse momento como um primeiro contato, ou convocação. Nele o crente é convocado a assumir uma tarefa especial na obra de Deus. Nos casos específicos que ora analisamos, a posição de pastor. Na trajetória de Ivan, a convocação se deu quando uma irmã o abordou afirmando que Deus queria enviá-lo para o campo missionário. Ainda que essa experiência tenha a dimensão de uma "profecia", ou de uma "revelação de Deus" proferida por um irmão "ungido", o convocado ainda não entende necessariamente a dimensão do que está acontecendo, ou melhor, está por acontecer.

Acontecimentos semelhantes se deram com Rafael (30 anos, Igreja Vida e $\mathrm{Paz}$ ). Ele recebe uma profecia quando saía de casa para trabalhar (Rafael acumula a 
função de pastor recém-ordenado com o trabalho em um frigorífico de um supermercado). Um irmão se aproxima dele e decreta: "Deus está me dizendo que você tem o dom da Palavra." Rafael conta os desdobramentos deste episódio:

Daquele dia em diante eu comecei a pensar um pouco mais nisso... Eu me lembro de que muitas das vezes eu me senti incomodado pra ler a Bíblia, eu ficava inquieto para ler a Bíblia, e quando todo mundo ia dormir lá em casa... Eu dividia o quarto com meu irmão, então eu tinha que ler a Bíblia com uma lanterna pra não incomodar... Eu ficava inquieto, eu queria conhecer, eu queria ler. E eu não sabia ainda que no futuro eu fosse precisar muito disso... A partir daquele dia eu comecei a pensar: "Eu tenho o dom da palavra?"... Desse dia em diante eu pensei [mais nisso], mas não se manifestou nada em mim que [alguém] pudesse dizer: "Eita, esse aí vai pregar em cima de um altar." Porque eu era muito tímido, né.

Enquanto Ivan já mostrava desde cedo o desejo no coração pelas coisas do Egito, Rafael, por sua vez, conta sua motivação incomum pelo conhecimento da Palavra (sentia-se "incomodado para ler a Bíblia", "ficava inquieto", "queria conhecer"). Esse desejo, sem motivo aparente inicial, faz parte da narrativa do chamado, na medida em que está em jogo a declaração latente de que ele foi colocado lá, no coração, pelo próprio Deus. A partir daí, a convocação surge como um chamado a uma preparação mais intensa, o início de um caminho em busca do virtuosismo espiritual. Este, por hora, não pode se concretizar dadas as imperfeições dos vocacionados, como a timidez de Rafael e o fato de Ivan ainda não estar casado, e sequer namorando, ainda que a profecia a ele direcionada mencionasse sua ida ao campo missionário em família. Esse reconhecimento da falta de preparo necessário para a concretização do chamado, quando do momento da convocação, não gera desconfiança em relação à sua veracidade. Ao contrário, é parte essencial na confirmação da narrativa, que visa mostrar o vocacionado como escolhido, e posteriormente preparado por Deus, não importando as condições (sociais, intelectuais, psicológicas) nas quais ele se encontrava. O objetivo da narrativa, enfim, é mostrar, ou mais ainda, provar que as situações nas quais se deram as convocações foram providenciadas por Deus, dentro da trama traçado por este para tornar os convocados pastores e líderes. Enfim, o interesse do vocacionado é mostrar que foi Deus quem o chamou, mesmo contrariando todas as probabilidades. É a construção desse critério de plausibilidade um dos requisitos para que os relatos sejam legitimados.

Esta busca por enquadrar-se nos requisitos de uma ideologia da linguagem específica nos leva a mais uma etapa da construção do relato do chamado: as confirmações. Por confirmação refiro-me à busca do que na ideologia semiótica pentecostal é entendido como evidência da convocação. É quando o propósito de Deus para a vida dos 
envolvidos torna-se mais uma certeza do que um conjunto indefinido de possibilidades. Mais uma vez, destaca-se aí uma ocasião mística, desta feita que não deixa dúvidas tanto no vocacionado quanto na comunidade da qual faz parte de que se trata de alguém escolhido por Deus para realizar a sua obra. Ivan (26 anos, Advec) conta o que se deu em um culto no qual o pregador pede ao líder da juventude da Advec para ficar de pé, pois tinha uma mensagem para ele. Como se tratava de uma comissão de liderança, Ivan não atende a convocação. $O$ pregador insiste e diz que a mensagem era especificamente para o líder presente em uma reunião naquela tarde junto com os pastores:

Só tinha eu mesmo, não tinha como escapar. Então eu levantei a mão e me identifiquei. E ele falou: "Assim diz o Senhor, Deus tem visto a dedicação que você tem tido à obra d'Ele. Ele tem te visto no serviço da casa do Senhor, como você tem cuidado dos pastores. Do jeito que você tem feito, Deus vai fazer com você. Deus vai levantar você com muita pressa para pastorear as ovelhas." E começou a dizer tudo o que Deus faria na minha vida, tornando público o chamado que Deus havia entregue a mim ainda pequeno. (Ivan, 26 anos, Advec).

Rafael (33 anos, Vida e Paz), por sua vez, conta um sonho que confirma seu chamado:

Eu sonhei que estava em uma grande piscina, uma piscina muito grande de água muito limpa, mas eu não estava sozinho. Muitas pessoas cercavam aquela piscina, e todas, iguais a mim, com vara na mão, pescando. Todos. Mas, o que era estranho? A piscina era mais comprida do que larga e eu estava em uma das extremidades e as outras pessoas cercavam a piscina, e eu me lembro que eu estava pescando e achei estranho como os peixes começaram a vir até mim. Os peixes iam pegar a isca dos pescadores que estavam ali, mas não iam até eles, pegavam a isca [mas não eram fisgados], desviavam a direção e vinham todos pra mim. E como a água da piscina era muito limpa, muito clara, dava pra ver aquele cardume na minha frente, esperando que eu pescasse. E interessante ainda foi que todos que estavam na piscina se revoltavam contra mim. Se chateavam porque eu estava pescando. Eles não entendiam porque os peixes não iam até eles, mas estavam vindo até mim. Naquela noite o sonho foi muito evidente, muito forte, muito nítido. Eu me lembro que no outro dia fiquei muito chocado com aquilo, muito impactado. Daquele dia em diante eu vi que o negócio era muito sério. (Rafael, 33 anos, Vida e Paz).

Aqui já não restam mais dúvidas a Ivan e Rafael de que Deus teria um chamado para suas vidas. Dentre os 450 jovens participantes do congresso em Natal, Ivan 
é escolhido para receber a profecia que revelava a todos o seu chamado. Rafael, na ocasião do sonho relatado, percebe que "o negócio era muito sério". As confirmações, portanto, parecem representar o clímax na narrativa de construção do sentido do vocacionado como alguém escolhido por Deus para seguir a carreira pastoral. Esse processo, da convocação às confirmações, vai moldando as subjetividades dos candidatos, preparando-os para essa carreira, movendo-os de incertezas envolvidas em um conjunto de eventos confusos em um primeiro instante, em direção à construção de um relato pleno de significado, em que os pontos, outrora desconexos, já estão perfeitamente amarrados. Ou seja, que o vocacionado foi eleito, sem dúvida alguma, por Deus, para seguir o ministério de pregador da Palavra.

\section{O Chamado e a Mitopráxis das Narrativas Bíblicas}

Um aspecto indispensável no processo de construção da narrativa do chamado é a Mitopráxis (Sahlins 2011) dos dramas bíblicos. Entendendo a práxis como uma "sociologia situacional do significado" (Sahlins 2011:17), o que Sahlins chama de Mitopráxis, de forma simplificada, consiste na recriação de mitos em circunstâncias contemporâneas. Ao engajarem-se em novos eventos a partir de tramas já estabelecidas em sua mitologia, Sahlins nos mostra como os personagens míticos servem como padrões de comportamento para os polinésios: a história havaiana se repete primeiro como mito, depois como evento. Com isso, "as pessoas comuns podem se comportar como se elas mesmas fossem personagens mitológicos" (Kuper 2002:228). As experiências de protagonistas míticos famosos passam a ser vivenciadas novamente pelos vivos em situações análogas. Mais ainda, os vivos têm a possibilidade de se tornarem heróis míticos.

No caso dos vocacionados ao pastorado pentecostal que ora analiso, é possível perceber com nitidez a tentativa de uma criação do mito de si mesmos a partir dos mitos bíblicos. Quando perguntei a Ivan sobre a possibilidade de existirem dúvidas em relação à sua vocação, obtive resposta na qual esse processo salta aos olhos:

A gente, como ser humano, não é que a gente duvide da bíblia, mas a gente acaba lembrando que Deus nos prometeu algo que não chegou até agora. Foi o que aconteceu com Calebe. Já tinham se passado 45 anos de quando ele recebeu a promessa de herdar a terra a terra prometida, e nada ainda. Mas veja o que Calebe falou para Josué: "Josué, eu quero a minha herança. Porque estou forte do mesmo jeito que há 45 anos. Eu quero a minha herança." E durante esses 45 anos você acha que Calebe não duvidou? Duvidou, sim! Muitas vezes. Mas acabou voltando para o foco. Esse é o diferencial entre quem duvida e quem desiste. Duvidar? Todo mundo vai passar por isso. Desistir é outra coisa. Porque [você] vai acabar lembrando do que Deus fez na vida das pessoas, do que Deus 
fez através de sua Palavra. Deus prometeu a Abraão um filho! Abraão tinha 75 anos. Era velhinho. Já tava falhando (risos). E Sara, além de ser velha, era estéril. Ela já estava com 65 anos. Mas Deus falou que [ela] ia ter [um filho]... E veio Isaque. A dúvida virá. Mas a diferença é a gente se lembrar de que Deus não mente, que Deus não volta atrás naquilo que prometeu.

Ivan vai da narrativa de Calebe (um dos protagonistas, juntamente com Josué, da chegada de Israel à terra prometida, descrita no livro bíblico de Josué, após a libertação do Egito) à do patriarca Abraão e sua esposa Sara (contida no livro bíblico de Gênesis) para dizer que a espera pelo cumprimento das promessas de Deus em sua vida é a mesma desses personagens. A conduta e os afetos dos personagens míticos, o foco, a confiança, a esperança e a fé são as mesmas, ou pelo menos devem ser as mesmas de Ivan.

A mitopráxis também acontece na conversa com Rafael. Quando perguntado sobre o tempo transcorrido entre o momento em que se tem consciência do chamado, o primeiro contato, até sua plena realização, a resposta é baseada no mito do chamado de Davi. Samuel, o profeta bíblico, vai à casa de Jessé, pai de Davi e pede para ver seus filhos dizendo que dentre eles seria ungido o rei de Israel. Jessé subestima o filho Davi, que estava a pastorear ovelhas e de início sequer o chama. Mas era justamente Davi, no entanto, que seria escolhido rei de Israel.

- E foi o que aconteceu comigo, disse-me Rafael.

- Davi recebeu aquela unção ali, mas Davi não foi rei [imediatamente] a partir dali. Ele tinha a unção de rei, mas não foi [coroado] rei [naquele instante]... Eu fui chamado naquele dia, fui alertado naquele dia, mas eu não sabia como isto iria acontecer.

Rafael é como Davi. Espera ser honrado como Davi o foi, ainda que Jessé, seu pai, ou quem quer que seja, não acreditasse na possibilidade de ele ser escolhido por Deus (lembremos das pessoas irritadas com Rafael em seu sonho pelo fato dos peixes se dirigirem a ele e não aos outros). Rafael foi alertado de seu chamado da mesma forma que Davi, e como ele, espera ser "ungido rei".

É importante acrescentar ainda que, ao realizarem a mitopráxis dos dramas bíblicos em suas narrativas do chamado, os vocacionados (como os polinésios) utilizam como modelo de ação não apenas os personagens míticos da Bíblia como Davi, Samuel, Calebe, Josué, Abraão e Sara, mas também personagens históricos como Silas Malafaia, Valdemiro Santiago, Davi Miranda, etc.: todos, líderes carismáticos consagrados que consolidaram a construção do mito de si mesmos. Campos \& Mauricio Junior (2013) mostram como Valdemiro Santiago, em suas mensagens, refere-se a si mesmo como um "simples comedor de angu", oriundo da roça, tornado 
agora apóstolo, líder da Igreja Mundial do Poder de Deus. Bem como Silas Malafaia denomina-se, quando do início de sua carreira, um mero "batedor de bombo", já que esta era a sua tarefa nos desfiles organizados pela igreja de seu sogro, a então Assembleia de Deus Ministério Penha, hoje Assembleia de Deus Vitória em Cristo (Advec), presidida pelo próprio Malafaia. Não é surpresa, portanto, ouvir Rafael construir um mito de si mesmo referindo-se à sua condição no início de carreira como "um jovem tímido", "incapaz", e "ainda muito pequeno para se encaixar neste cargo [de pastor]", não tendo ainda "palavra nem sequer para dez minutos de pregação, por falta de experiência”. Mas que, todavia:

Quando largava [do trabalho]... Chegava durante o culto e ficava na janela vendo as pessoas pregarem. Absorvendo informação da janelinha da igreja, sujo, fedendo a charque ainda [já que trabalhava, e ainda trabalha, em um frigorífico] e ficava ouvindo as pessoas pregarem, os pregadores de fora [ou seja, pregadores de outras igrejas convidados especialmente para a ocasião].

Até chegar o momento em que, segundo ele mesmo, sua carreira "toma a proporção que tem hoje", referindo-se ao fato de ter sido designado para pastorear uma congregação (filial) da igreja Vida e Paz no bairro da Várzea, em Recife, além de ter sido escolhido como pregador na noite de abertura do Congresso de Homens de sua igreja. Rafael já seria, em seus termos, rei como Davi.

\section{Ser usado por Deus}

A condição sine qua non um crente ordinário não teria como elevar-se acima dos seus, destacando-se para começar a assumir os cargos de liderança em sua igreja local até ser conduzido ao pastorado, e daí talvez ao estrelato é a de ser usado por Deus. E, para o pastor pentecostal, ser usado por Deus significa principalmente "trazer uma palavra da parte do Senhor". Essa preocupação cerca os pregadores constantemente: ser mensageiro de Deus para aqueles que o ouvem. Assim, a atividade pela qual o pastor será reconhecido efetivamente como pessoa cheia do Espírito Santo, e que determinará se ele será lembrado ou não como alguém realmente usado por Deus é a prédica pentecostal. É no púlpito, pregando para os fiéis, que o papel do pastor é forjado e onde a comunidade o reconhece como pessoa "ungida", "abençoada", "homem de Deus", "enviado do Senhor". O pastor, portanto, é acima de tudo um pregador. E ser usado por Deus é pregar poderosamente.

Vários autores (Coleman 2000; Engelke 2007; Robbins 2004), ao elencarem as principais características do movimento pentecostal, geralmente começam por relatar a crença dos seus fiéis no poder do Espírito Santo e nas experiências extraordinárias constituídas a partir do contato íntimo e pessoal com a terceira pessoa da 
trindade. Posso afirmar, assim, que o crente pentecostal está sempre na busca pela próxima experiência transcendental. Uma nova experiência que confirme ou suplante a anterior é o objetivo à frente de todo crente pentecostal e é a partir dessa busca que o fiel vai assumindo as subjetividades do sujeito convertido ideal (ver Campos \& Mauricio Junior 2012). E o pregador está ali justamente para assegurar que essa busca seja bem-sucedida. Seu papel é o de dínamo de novas experiências (Campos \& Mauricio Junior 2013). E ele as promove conduzindo seus ouvintes pelos caminhos de sua prédica, levando-os do fluxo ordinário da vida cotidiana a um momento liminar, disposto betwitxt and between (Turner 2005b) o caminho que sai da vida ordinária e a ela retorna.

Para apresentar o modelo da prédica bem-sucedida, repleta de formas sensoriais e que promove experiências na vida dos fiéis, usarei o exemplo do principal palestrante da Eslavec, Thomas Dexter Jakes (T. D. Jakes) ${ }^{10}$ renomado pregador internacional e atração ansiosamente aguardada pelos congressistas que acompanhei. ${ }^{11}$ Logo depois, apresentarei a forma como a subjetividade do vocacionado vai sendo constituída a partir dos resultados de suas próprias experiências com a prédica.

"O nosso Deus é um Deus de estratégias", assim Jakes dá início à sua fala. Seu tom, inicialmente, é professoral. Todos estão a postos com o caderno de anotações incluso no material do congresso para não perder nada do que seria dito ali. $O$ pregador continua calmamente, seus gestos acompanham o ritmo de suas palavras:

Ele tem um plano. Ele não se move atropeladamente. Ele tem um propósito. O livro de Efésios diz: Ele trabalha em todas as coisas depois do conselho, (repete) depois do conselho da sua própria vontade. A maioria das empresas é conduzida por um corpo de diretores, e cada posição na diretoria contribui para decidir as estratégias da companhia. Mas Deus se aconselha com ele mesmo...

O tom vai aumentando. A velocidade e a rotação com a qual as palavras são ditas também aumentam paulatina e decididamente. Suas mãos parecem sustentar o caminho das palavras no ar, como numa tentativa de sublinhar cada dizer. É como se diante dele houvesse um teleprompter ${ }^{12}$ porque parece difícil que tantas coisas sejam ditas nesta velocidade na qual sobra espaço apenas para respirar poucas vezes, sem tropeçar nas palavras e sem nenhum tipo de hesitação na costura das frases. Suas palavras são amarradas umas às outras cada vez mais rápida e intensamente, sem nenhum escorregão na dicção, nenhuma perda de ritmo no fluir de seus dizeres: “... Ninguém o dá conselhos. Ninguém o aponta nada. Ninguém o elege. Ele é Deus por ele mesmo. Ele se encontra consigo mesmo. Ele decide sozinho...".

Como o narrador de uma partida de futebol, aumentando o tom e a dramaticidade de sua fala na medida em que o time se aproxima da meta, Jakes atinge a rotação máxima. Seus olhos, vidrados na audiência. Seu corpo parece eletrificado. As pes- 
soas, como se estivessem na arquibancada vibrando com a aproximação da conclusão de uma grande jogada, sentam-se na ponta das cadeiras, prestes a se levantarem e pular diante do maior êxtase proporcionado aos aficionados por uma partida de futebol. Jakes continua: “... Ele se move por ele mesmo. E quando ele se move ninguém pode detê-lo. Ninguém pode acrescentar nada, nem tirar nada dele...” O pregador agora exclama a plenos pulmões: "Somente Ele é Deus!" Muitos já estão de pé, aplaudindo. Gritando Glórias e Aleluias. Levantando as mãos. Ele repete várias vezes, já aos gritos: "Somente Ele é Deus, somente Ele é Deus. E além dele não há outro." A multidão já esbraveja junto. Chamar o pregador de maestro não combinaria com a quietude da audiência de um concerto, ainda que Jakes pareça estar conduzindo toda aquela efervescência, verbal e corporal, com sua batuta. $O$ pregador ferve, e a multidão também. Já aos pulos, Jakes conclui com um convite: "Sinto que devo louvá-lo. Alguém me ajude a louvá-lo." Eu poderia jurar que senti o local tremer. Depois de alguns instantes imersos nessa euforia, Jakes retoma o compasso mais próximo de um adágio do que de um prestíssimo e lê o texto bíblico que será a base de sua mensagem:

"No princípio era o Verbo, e o Verbo estava com Deus, e o Verbo era Deus. Ele estava no princípio com Deus... E o Verbo se fez carne, e habitou entre nós" (João $1: 1-3,14)$. Jakes inicia a dramatização do texto e parece tentar o mesmo efeito obtido por Caravaggio quando pintou Tomé, o Incrédulo: levar a quem olhasse sua obra a quase poder sentir o toque de Tomé na carne de Jesus, o verbo feito carne. Jakes repete: “... E o verbo se fez carne..." E a cada vez, das várias em que repetiu esta frase, prolongava a última sílaba como se o som reverberasse, propagando-se no ouvido dos fiéis (and the Word was made flesh - shhhhhhh). Jakes chama a atenção do público: "... Escute isso agora”. Não era necessário, todos estavam com os olhos fitos nele. E o que está por vir consiste no que entendo ser justamente uma das incumbências do pregador no ritual da prédica. Diz Jakes:

... [se] o verbo se fez carne, o plano foi feito carne. A estratégia foi feita carne. $\mathrm{O}$ abstrato foi feito concreto. O invisível foi feito visível. Isso é uma missão. É um chamado. Isto é um encargo: Que nós peguemos o que foi escrito para fazer disso carne. Nós vamos andar na palavra (walk out the world), falar a palavra (talk out the world). [Precisamos falar] que a palavra foi feita carne e habitou entre nós... É para isso que estamos aqui, para que o mundo possa ver o verbo feito carne.

Fazer da palavra carne, como afirma Jakes, é a missão do pregador. É dando vida ao texto a partir da performance que o pastor promove o sentido da presença do Espírito Santo entre os participantes do culto. As "regras básicas da performance" (Bauman 1975) da prédica são as formas sensoriais, ou os modos autorizados pela ideologia semiótica pentecostal considerados indispensáveis para o acesso ao transcendente. Ao serem executadas na performance da prédica, essas regras básicas, além 
de construir o sentido da presença do Espírito Santo, geram sensibilidades particulares modelando as subjetividades tanto dos fiéis como também dos próprios pregadores.

Chamo de desvendamento a primeira forma sensorial estruturadora da prédica que apresentarei. Minha intenção com o termo é transmitir a imagem de alguém que, mesmo diante do texto bíblico, ainda não consegue perceber a profundidade, ou as verdades ocultas na mensagem, sendo o pregador o responsável por retirar a venda. O momento paradigmático da mensagem de Jakes para ilustrar o que entendo por desvendamento acontece quando, após continuar a leitura do texto até o momento em que Jesus pede água do poço de onde a mulher samaritana a retirava, ele admoesta: "Catch this Picture." E em um tom de quem estava prestes a trazer uma grande revelação, afirma, "Jesus é o poço em cima de outro poço". Faz uma pausa dramática e, ao dizer "Look at this picture", conclama todos a imaginarem a cena enquanto repete "Ele é o poço, sentado no outro poço..." com a mesma sincronia verbal/corporal já relatada anteriormente, antecipando cada repetição por uma pausa breve, como que para averiguar a reação dos ouvintes: “... o poço sentado no outro poço... o poço sentado no outro poço." As primeiras pessoas começaram a reagir com glórias e aleluias. Era como se uma lâmpada se acendesse sobre a cabeça de cada um que percebesse o que Jakes queria dizer com aquela metáfora. E as lâmpadas começaram a se multiplicar rapidamente como se uma contribuísse para acender imediatamente outra ao seu lado, sempre acompanhado, este desvendamento, por um sorriso tanto de satisfação como de perplexidade. Ele continua: "A mulher ia costumeiramente até ali e encontrava um poço. Dessa vez ela encontrou dois poços. Um poço de água normal e outro de água viva." É aí que as vendas de todos os presentes parecem cair e ele convida: "Se você está entendendo o que estou dizendo, dê um aplauso e um brado de vitória."

Quando perguntei a Ivan (Advec) que momento da Eslavec teria sido mais marcante para ele, esse é o momento relembrado. O sorriso de satisfação retorna à face de Ivan, o mesmo que vi nos rostos de tantos outros naquele dia. Ele diz:

Eu sempre tinha lido isso aqui da mulher samaritana em João 4 e nunca tinha conseguido entender, cara. Aí ele vai e diz que Jesus era um poço em cima de outro poço. Glória a Deus, cara! Como é que ele diz um negócio desses? Que sabedoria é essa em aplicar o texto!? Aquilo me marcou extremamente na Eslavec. Demais, demais! A gente acaba chamando isso de revelação do texto, do que está nas entrelinhas. Na busca por conhecimento a gente acaba vislumbrando na Palavra algo que a gente acabou não vendo mesmo lendo aquele texto por mais de cem vezes.

A segunda forma sensorial que estrutura a performance da prédica diz respeito ao uso do corpo do pregador. Já mostrei como Jakes executa uma coreografia no púlpito enquanto conduz a multidão. Em um momento da mensagem, Jakes pergunta à sua audiência: "O que está acontecendo com a liderança hoje? Não é uma lide- 
rança de verdade." E depois começa a andar em círculos por todo o palco, enquanto o tradutor o segue:

Se eu começar a andar e o meu tradutor começar a andar após mim, ele não está liderando, ele está me seguindo. Quando você anda por onde alguém já andou, você não está liderando, você está seguindo. O sinal de um grande líder é andar por onde ninguém andou ainda e se você tiver coragem de andar por onde ninguém jamais andou antes, as pessoas não irão entender. Eles vão te criticar. Quem anda primeiro recebe um monte de críticas, mas continue a caminhar... Continue a caminhar... Continue a caminhar...

Daí se sucede o que já vimos acontecendo até aqui. Cada repetição do "Continue a Caminhar" funciona como um convite para que as pessoas entrem em uma dimensão ritual superior, efervescente, junto com o pregador. Mas o que pretendo destacar agora é como o tradutor revela a necessidade de se compor o "frame" (Bauman 1975, Goffman [1959] 2009) da performance da prédica com o corpo. O tradutor não segue Jakes somente porque este dá a deixa. Ele poderia simplesmente ser alocado em uma cabine de onde ouviria o pregador e procederia com a tradução simultânea. Aqui, porém, isso não é possível. Está implícita na ideologia semiótica pentecostal a necessidade de o tradutor tentar manter a mesma rotação da sincronia verbal/corporal do pregador, a fim de não atrapalhar a eficácia da performance. Quando Jakes, continuando sua exortação aos líderes presentes, diz "Eu vim lá de Dallas, Texas, para fazer uma revolução... para te desafiar. Cruze a linha", ele começa a dar passos largos até que pula a caixa de som que estava aos seus pés e lhe servia de retorno. $\mathrm{O}$ tradutor, pastor Gidalte Alencar, segue-o e também pula a caixa de som gritando em português, logo após Jakes bradar em inglês: "Faça algo radical. Deus te chamou para liderar!"

A terceira e última forma sensorial que apresentarei é a liberação de palavras proféticas. Profetizar parece exigir do pregador uma sintonia maior com o transcendente já que, por profecia, os pentecostais entendem a declaração antecipada de fatos ainda por acontecer. Referem-se ao ato de profetizar como "liberar" uma profecia, para realçar o sentido de que algo estava guardado, somente esperando a "liberação" (por parte de Deus) através do pregador. Em um dos cultos em que acompanhei o pastor Rafael (Vida e Paz), testemunhei uma profecia "liberada" por ele. Depois, entrevistando-o, questionei:

- Aquilo estava programado? Como é que acontece?

- Existem dois tipos de mensagem: a que eu quero pregar e a que eu tenho que pregar. Muitas vezes o que eu tenho que pregar eu não sei. Eu sei o que eu quero pregar. Eu tenho um texto, eu tenho uma avaliação criteriosa do texto... Mas tudo o que você vai falar, cem por cento, você 
não tem na hora... E acontecem em cima do altar [coisas como]: Eu estava ministrando uma palavra sobre o endemoniado, que o pai estava muito angustiado com aquela criança endemoniada... E quando eu li [o versículo bíblico] "sai dessa criança e não volta mais", eu falei assim: "Deus vai fazer alguma coisa na vida de pessoas que são da sua família. E quando Deus fizer, ele não vai fazer uma coisa que vai te deixar com dúvida. Ele vai fazer e vai te deixar com certeza"... "porque é pra sair e não voltar mais"... Aí saiu a palavra: "Ainda este ano Deus vai trazer alguém da sua família [para a igreja]". Menino, pense na responsabilidade que foi ali!! Saiu mesmo!!... Não é programado... Saiu da minha boca sem eu ter premeditado isso...

Deduz-se da fala de Rafael que o pregador, para profetizar, necessita estar à mercê de Deus de forma tal que não é possível sequer segurar a palavra demandada por Ele para ser entregue, liberada, pelo pregador. Como diz Rafael, a palavra "saiu", como se ele mesmo não tivesse condições de controlá-la. A profecia nitidamente está mais próxima de uma forma linguística centrífuga (Bialecki 2011), ou seja, que evidencia a agência fora do sujeito, uma vez que Deus revela diretamente a mensagem que deve ser transmitida. Ainda assim, reiterando a retroalimentação entre as formas linguísticas centrífugas e centrípetas, vê-se que mesmo esperando uma interferência do Espírito Santo, direcionando o que vai ser dito, Rafael precisa esforçar-se para fazer sua parte: estar de posse de "uma avaliação criteriosa do texto". Não se tem cem por cento do que se vai falar na hora, como ele diz, mas é preciso haver um preparo, e um desejo de preparar-se, por parte do pregador evidenciado na construção de um esboço sobre o qual o Espírito Santo irá expandir a experiência. $O$ desvendamento também exige uma habilidade adquirida a partir do trabalho do pregador em debruçar-se sobre o texto até que dali venha uma mensagem a ser transmitida com sua assinatura. A mesma retroalimentação entre formas de linguagem, ainda que a forma centrífuga fique em evidência, acontece com a narrativa do chamado. O desejo no coração, por exemplo, é posto por Deus e só será entendido a posteriori quando o chamado se confirmar. A convocação é feita por um irmão de fé, evidenciando uma agência externa ao sujeito, o que, mais uma vez, denota um aspecto centrífugo da linguagem. No entanto, Rafael precisa, após a convocação, assumir a tarefa de estudar incessantemente a bíblia a ponto de fazê-lo, segundo seu relato, sob a luz de uma lanterna as luzes do quarto que dividia serem apagadas.

Voltando à mensagem de Jakes, já no seu final, quando ele convoca todos os jovens presentes no congresso a receberem dele uma oração à frente do púlpito, quero ressaltar a dimensão da experiência. Ele diz:

Chegou o teu momento. Uma nova unção está vindo sobre você. Esta é a hora. - Nós colocamos o evangelho na TV, você vai colocá-lo no Facebook. Nós o colocamos no rádio e você coloca na internet. Alcance sua 
geração com uma nova unção... Eu quero que todos os jovens venham à frente agora. Corram até o altar. Corram até o altar! Venham até aqui rapidamente!

Ao meu lado, um jovem chamado Gabriel, que participava ativamente do culto, atende à convocação do pregador. Eu o sigo. O barulho das pessoas empurrando suas cadeiras e correndo até a frente do palco invadiu todo o lugar. Aqueles que ficaram não o fizeram como meros espectadores, limitando-se a vislumbrar o que acontecia, mas oravam em voz alta, bradavam impondo suas mãos na direção dos que estavam à frente. Parecia que todos os presentes haviam entrado em outra dimensão. Jakes agora se direciona para centenas de jovens já reunidos à frente do palco:

Preparem-se. Preparem-se para a glória do Senhor... Ele está para te usar de uma forma maior. Joguem fora suas dúvidas. Joguem fora seus temores. Joguem fora seus pecados. Deus está prestes a te usar de uma maneira impressionante... Você faz parte de uma geração escolhida. Chegou a tua hora. Você está pronto?

Muitos se ajoelhavam levando as mãos ao rosto. Vários chorando copiosamente enquanto respondiam com "Amém", "Sim, Senhor", "Glória a Deus" a cada frase anunciada pelo pregador. Era possível perceber a importância daquele momento para os presentes. Se o culto como um todo pertence à dimensão do sagrado, aquele momento do culto representava o instante sacratíssimo. Ao presenciá-lo, passei a entender o que diziam os fiéis por mim entrevistados quando se referiam às experiências inesquecíveis proporcionadas por Deus. Jakes dizia:

Deixe que as lágrimas venham. Não tem problema. Deus está fazendo algo dentro de ti. É sobre isto que tudo aqui se trata. - Vocês são os profetas, os pregadores, os pastores e os apóstolos da nova geração. Deus vai te usar como você nunca foi usado antes.

Todos voltam, e eu acompanho Gabriel de volta ao seu lugar e vejo-o abraçando efusivamente outro congressista enquanto dizia: agora eu sei. Depois de encerrado o culto, interpelei Gabriel sobre o que ele agora sabia: "Deus quer que eu seja pastor", ele me respondeu.

\section{Chamados para chamar}

Não obstante os momentos como acabei de descrever vivenciados por jovens como Gabriel, os vocacionados também têm suas subjetividades moldadas no exercício da performance da prédica, quando, em vez de recipientes da mensagem, eles 
mesmos conduzem a performance com o objetivo, como vimos, de multiplicar a experiência liminar a outros. Nessas ocasiões, uma espiral hermenêutica potencializada pelas experiências de confirmação afastam sentimentos culturalmente definidos como obstáculos à eficácia da performance, substituindo-os pelas emoções e afetos autorizados na ideologia semiótica pentecostal para potencializar o ritual da prédica. Rafael conta como isso se dá:

As confirmações que pesavam mais eram algumas coisas que se desenvolviam em mim aos poucos, e eu ficava pensando "Como é que eu fiz isso?", "Como é que isso aconteceu?". É você dar uma palavra em um culto e você não conhecer a pessoa, não conhecer ninguém e de repente, no final do culto, aquela pessoa vem falar contigo e diz assim: "Você falou isso e isso e isso, era minha vida todinha." E depois a pessoa voltar para você dizendo que Deus mudou a vida dela.

Alimentados, então, pela convicção de que a próxima performance pode ser ainda mais eficaz, uma vez que será informada pela sua antecessora bem-sucedida, os vocacionados avançam na sua hiperconversão e passam a ser entendidos pela comunidade e por si mesmos como líderes pentecostais. Os desdobramentos do episódio da palavra que "saiu" descrito por Rafael levaram-me a entender que suas habilidades em executar as formas sensoriais se tornaram mais aguçadas:

... Não deu uma semana: a irmã que estava na igreja, para quem eu disse a profecia ("ainda este ano Deus vai trazer alguém da sua família")... O marido dela chegou e se converteu, o que era a coisa que ela mais desejava. A mesma mensagem, no Viana (bairro de Camaragibe - PE), saiu a mesma coisa, quando li o [mesmo] trecho: "Deus vai restaurar sua família. Ele vai trazer pessoas da sua família." Duas irmãs vieram me dizer depois que pessoas de sua família passaram a frequentar a igreja após aquela palavra.

O mesmo afirma Tiago (Advec) quando conta sobre os momentos em que, no exercício da liderança dos jovens da Advec Caxangá, "dá uma palavra" aos seus liderados e recebe de volta as confirmações de sua eficácia: "Aí a pessoa chega depois [dizendo] 'Poxa, Tiago, obrigado. Aquela palavra falou ao meu coração. Era o que eu estava precisando escutar'. Aí você sente que foi usado por Deus."

Pr. Ítalo, por sua vez, afirma ter superado o medo que lhe acometeu na ocasião em que finalmente foi designado para o campo de Milhã, no interior do Ceará - segundo ele, "um medo de ter de enfrentar o que estava pela frente" - somente quando estava "dentro da coisa". Solicitado para lembrar algo acontecido depois que ele estava "dentro", conta: 
Nós tínhamos um programa de rádio lá em Milhã, e eu estava pregando a palavra de Deus, sobre a vida como presente de Deus... Eu senti que Deus me deu aquela palavra naquele momento, apesar de não ser a palavra que estava no esboço... Mas eu senti que Deus estava me usando, me direcionando a falar sobre aquilo porque alguém precisava ouvir. À noite, uma pessoa me procurou e disse: "pastor, eu estava determinado a tirar minha vida, eu já tinha amarrado a corda na madeira que sustenta o teto... e ao ouvir sua palavra eu desisti." E eu sabia na rádio que Deus estava me usando para falar especificamente com alguém, para abençoar alguém. Não sabia quem, onde nem como. E à noite, no mesmo dia, a pessoa foi, testemunhou na igreja que já estava com a corda amarrada, mas Deus falou naquele momento para que ela não fizesse aquilo.

E depois do acontecido, Ítalo chega à conclusão de que "não é só aquilo que você imaginava ser, é muito mais" porque, ele acrescenta, "Deus mostra que vai suprindo tudo". E, assim, os vocacionados vão se transformando em mestres da narrativa, costurando o relato de seus chamados e sendo usados por Deus para transformar outros e continuar o ciclo de expansão pentecostal.

\section{Considerações Finais}

Como disse Harding, falar é crer. No entanto, mostrei que a reforma da linguagem característica da conversão ao pentecostalismo está inserida em uma economia representacional mais ampla, normativamente organizada na ideologia semiótica pentecostal. Define-se, desse modo, e no mesmo feixe de relações, a hierarquia entre palavras, coisas e pessoas, bem como as formas sensoriais autorizadas a construir o sentido da imanência da transcendência no corpo dos fiéis. Uma retroalimentação, e às vezes uma ambiguidade, entre formas de linguagem/semióticas que, por um lado, evidenciam uma agência interna ao sujeito nas ações e fenômenos carismáticos e, por outro lado, localizam a origem dessas ações e fenômenos ação na alteridade do Espírito Santo ou do irmão ungido é a principal característica da ideologia da linguagem/semiótica aqui apresentada. É, portanto, no caminho de tornarem-se versados nessas formas de linguagem/semióticas que alguns crentes ordinários se envolvem no processo de hiperconversão. O objetivo é transformarem-se em mestres da narrativa, tendo, assim, sua vocação para cargos de liderança apontadas e confirmadas pela comunidade. Analisei aqui em profundidade esse processo de constituição do pastor pentecostal como hiperconvertido, tentando mostrar também como as dimensões da linguagem, da materialidade e da experiência estão aí entrelaçadas. Para construírem uma narrativa de si através da qual prestam contas à comunidade de que foram chamados por Deus e de que são usados por Deus, e, enfim, para proporcionarem às outras pessoas, fiéis ou não, as experiências tidas como inefáveis, um conjunto de 
formas sensoriais deve ser posto em ação pelos vocacionados. São as formas semióticas como a mitopráxis dos dramas bíblicos, a interpretação das confirmações e os recursos do desvendamento e da liberação de palavras proféticas que comprovam a vocação, ao mesmo tempo em que moldam a subjetividades dos jovens candidatos a pastor pentecostal.

\section{Referências}

AUSTIN, John Langshaw. ([1962] 1990). "Prefácio" e "Performativos e Constatativos". In: Quando Dizer é Fazer: Palavras e Ação. Editora Artes Médicas, Porto Alegre, p. 18-28.

BAUMAN, Richard. (1975), "Verbal Art as Performance". American Anthropologist, 77 (02): 290-311.

BIALECKI, Jon. (2011). "No Caller ID for the Soul: Demonization, Charisms, and the Unstable Subject of Protestant Language Ideology”. Anthropological Quarterly, Vol. 84, nº 3, p. 679-704.

BIALECKI, Jon; HAYNES, Naomi \& ROBBINS, Joel; (2008), "The Anthropology of Christianity". Religion Compass 2/6.

CAMPOS, Roberta B. C.; MAURICIO JUNIOR, Cleonardo. (2012), "Os Comensais da Palavra: Emoções e corpo na trajetória espiritual dos crentes da Assembleia de Deus". Revista Brasileira de Sociologia da Emoção, 11 (33): p. 777-799.

CAMPOS, Roberta B. C.; MAURICIO JUNIOR, Cleonardo. (2013), "As Formas Elementares da Liderança Carismática: O verbo e a imagética na circulação do carisma pentecostal". Mana 19(2): 249-276.

CANNELL, Fenella. (2006), The Anthropology of Christianity. Duke: Duke University Press.

COLEMAN, Simon. (2000), The globalization of Charismatic Christianity: spreading the gospel of prosperity. Cambridge: Cambridge University Press.

COLEMAN, Simon. (2003), "Continuous Conversion? The Rethoric, Practice and Rethorical Practice of Charismatic Protestant Conversion”. In BUCKSER, Andrew \& GLAZIER, Stephen D. (eds.). The Anthropology of Religious Conversion, p.15-27. Lanham: Rowman \& Littlefield Publishers, inc.

COLEMAN, Simon. (2006), "Materializing the self: Words and gifts in the construction of charismatic cristianity identity". In: F. Cannell. The Anthropology of Christianity. London. Duke: Duke University Press, pp. 163-184.

COLEMAN, Simon. (2018), "Zonas fronteiriças: ética, etnografia e o cristianismo 'repugnante”. Debates do NER, ano 19, n 33, p. 271-312.

KEANE, Webb. (2002), "Sincerity, 'Modernity' and the Protestants". Cultural Anthropology, 17: 65-92.

KEANE, Webb. (2007), Christian Moderns: Freedom and Fetish in the Mission Encounter. Berkeley: University of California Press.

KEANE, Webb. (2018), "On Semiotic ideology". Sign and Society, 6(1): 64-87

KUPER, Adam. (2002), "Marshall Sahlins: História como cultura”. In: Cultura: A visão dos Antropólogos. EDUSC. p. 207-258.

MAFRA, Clara. (2014), "Santidade e Sinceridade na Formação da Pessoa Cristã". Religião e Sociedade, 34(1).

MAURICIO JUNIOR, Cleonardo. (2014), "Cristianismo e conversão: uma breve revisão". Revista Anthropológicas, 25 (1): 195-210.

MAURICIO JUNIOR, Cleonardo; CAMPOS, Roberta. B. C. (2018), "O Pentecostalismo nas fronteiras da Antropologia: Uma apresentação a 'Zonas fronteiriças: Ética, Etnografia e o Cristianismo repugnante'. Debates do NER, vol.1, no 33, p. 263-270.

MEYER, Birgit. (2010), "Aesthetics of Persuasion: Global Christianity and Pentecostalism's Sensational Forms". The South Atlantic quarterly, 109 (4): 741-764. 
MEYER, Birgit. (2018), "A estética da persuasão: As formas sensoriais do cristianismo global e do pentecostalismo". Debates do NER, ano 19, n. 34, p. 13-45

MEYER, Birgit. (2019), "Religião Material: como as coisas importam". In: E. Giumbelli, J. Rickli, R. Toniol. Como as coisas importam: uma abordagem material da religião. Porto Alegre: Editora Ufrgs

REINHARDT, Bruno. (2016), "De epifania a método: a teopolítica do testemunho em um seminário pentecostal em Gana”. Religião $\mathcal{B}$ Sociedade, 36(2): 44-70, 2016

ROBBINS, Joel. (2003), What is a christian? Notes toward an anthropology of Christianity. Religion 33.

SAHLINS, Marshal. ([1987] 2011), Ilhas de História. Rio de Janeiro: Zahar.

TURNER, Victor. (1982), From Ritual to Theatre: The Human Seriousness of Play. New York: PAJ Publications.

TURNER, Victor. (1988), The Anthropology of Performance. New York: PAJ Publications.

TURNER, Victor. (2005), "Dewey, Dilthey e Drama: um ensaio em Antropologia da Experiência (primeira parte), de Victor Turner”. Tradução: Herbert Rodrigues. Revisão: John C. Dawsey. Cadernos de Campo, no 13: 177 - 185.

TURNER, Victor. (2005b), "Betwixt and Between: o período liminar nos ritos de passagem". In: V. Turner. Floresta de Símbolos: aspectos do ritual Ndembu. Niterói: Eduff.

\section{Notas}

1 A $4^{\circ}$ Escola de Líderes da Associação Vitória em Cristo se deu em Águas de Lindoia - SP (a 180 km de São Paulo capital, $65 \mathrm{~km}$ de Campinas), de 11 a 15 de dezembro de 2012. O evento é direcionado para a formação de líderes evangélicos e tem como intuito promover "o preparo e ensino das pessoas que vão lidar com o povo", visando o "crescimento com qualidade", segundo o próprio Silas Malafaia, líder do evento, na sua fala de abertura do Congresso. A Eslavec surgiu a partir de sua participação em uma escola de líderes nos Estados Unidos, a School of Ministry, promovida pelo Pr. Morris Cerullo, um dos televangelistas mais conhecidos no mundo. Lá, Malafaia afirma que o Espírito Santo o teria convocado para fazer uma escola de líderes semelhante no Brasil. Assim, a primeira edição da eslavec aconteceu em 2009, contou com mil participantes e foi sediada em um hotel. A edição onde fiz trabalho de campo, por sua vez, já contava com cinco mil inscritos e acontecia na praça central da cidade, em duas tendas gigantes com ar refrigerado e com vários hotéis fechados exclusivamente para participantes do evento.

2 Minha entrada na Escola de Líderes se deu porque a coordenação do evento não apresentava resistência à participação de pessoas em geral, apesar de direcionar a programação a líderes evangélicos. Ao fazer minha inscrição no site da Eslavec, deixei em branco a parte do formulário que fazia referência à igreja de pertencimento e paguei a taxa de participação que incluía as diárias no hotel.

3 Silas Malafaia, pastor da Assembleia de Deus Vitória em Cristo, é uma das principais lideranças evangélicas pentecostais no Brasil. Sua trajetória revela atuações tanto no âmbito eclesial quanto no televangelista. Com formação em teologia e psicologia e também bastante talento para a comunicação, ao longo das décadas de 1980 e 1990 amplia sua popularidade como pastor, apresentador e conferencista, seja por meio da apresentação do programa Vitória em Cristo (conhecido anteriormente como Impacto), seja por meio da organização e realização de grandes eventos evangélicos, no Brasil e exterior. Nos últimos anos, ele passa a ocupar a arena política com mais frequência, na medida em que se envolve em debates sobre temas morais controversos, a exemplo principalmente daqueles que dizem respeito aos direitos civis dos grupos LGBT. Nesse cenário, a retórica e a liderança de Silas Malafaia passam a ser desafiadas por grupos de ativistas que articulam agendas feministas, LGBT, militantes em defesa do aborto, entre outras bandeiras que enfatizam a urgente necessidade de uma abordagem estritamente secular sobre essas questões.

4 A Associação Vitória em Cristo tem foco em divulgar o trabalho pessoal do pastor Silas Malafaia, distinto do que faz na sua igreja. Aqui é a imagem do pastor que é explorada.

5 A Assembleia de Deus Vitória em Cristo, Advec, originou-se de um entre tantos rachas ocorridos nas Assembleias de Deus. Era conhecida anteriormente por Ministério Penha e, sob a liderança do pastor José Santos, contava com 85 igrejas espalhadas exclusivamente pelo estado do Rio de Janeiro, instalando-se preferencialmente em bairros periféricos. Após o falecimento de José Santos, seu genro, o pastor Silas Malafaia, assume o Ministério Penha, separa-se da Convenção Geral das Assembleias de Deus no Brasil (CGADB) e muda o nome de sua igreja 
para Vitória em Cristo, mesmo nome do programa televisivo que comandava há anos. Desde que transformou o Ministério Penha em Vitória em Cristo, em 2010, Malafaia elevou para cerca de 100 o número de suas filiais no Rio de Janeiro, instalando-se também em bairros nobres como Barra da Tijuca e Recreio dos Bandeirantes, além de construir o megatemplo que serve hoje como sede da sua igreja, no próprio bairro da Penha. Além disso, Malafaia promoveu um ambicioso movimento de nacionalização de sua igreja. Outros megatemplos foram inaugurados em São Paulo, Brasília e Curitiba, como também igrejas menores em vários outros estados brasileiros. Pernambuco é o segundo estado em quantidade de templos da denominação. A internacionalização da igreja já foi também iniciada com a inauguração de filiais em Portugal.

6 A igreja batista missionária vida e paz é uma denominação de bairro, e faz parte do que se entende por igreja renovada, grupo que se "pentecostalizou" e rachou com as igrejas tradicionais.

7 A maioria das tradições pentecostais ainda não facultam às mulheres a possibilidade de serem pastoras. Mesmo dentre as igrejas que abrem essa possibilidade, como é o caso da Advec, são geralmente os homens aqueles que são considerados mestres da narrativa da prédica, sendo apontados como futuros pastores.

8 Todos têm posições de liderança na igreja mesmo antes de serem oficializados como pastores. Antes de se chegar ao cargo de pastor, os vocacionados vão assumindo diferentes papéis na igreja também como forma de preparação.

9 O termo ministério aparece no contexto pentecostal em diversos sentidos. Pode significar vocação, como também as subdivisões das igrejas Assembleias de Deus, que podem ou não se submeter a uma convenção nacional e que na prática funcionam como denominações independentes mantendo o carisma do nome da instituição (ex.: Assembleia de Deus Ministério Belém, Ministério Madureira etc.).

10 T. D. Jakes é americano e pastor da megaigreja The Potter's House (com mais de 30 mil membros segundo seu website oficial, em Dallas, EUA. Além de comandar sua igreja, Jakes também é escritor de diversos livros e produtor de filmes voltados para o público evangélico. Em 2001, foi eleito, pela revista Time Magazine, o melhor pregador americano, sendo comparado por esta publicação ao maior fenômeno televangelístico da história americana, Billy Graham (Time, 17 de setembro de 2001, vol. 158, n. 11). A capa desse número trazia uma foto de T.D. Jakes acompanhada dos dizeres "Is this man the next Billy Graham?" ("Este homem é o próximo Billy Graham?", tradução livre). Seu ministério, T. D. Jakes Ministries, promove grandes eventos que lotam estádios por todo os EUA.

$11 \mathrm{O}$ evento teve início na terça à noite com uma pregação do Pr. Silas Malafaia. A partir daí, até a sexta-feira, a programação constou de três cultos diários. Dois acontecendo pela manhã, sendo que em um deles, no primeiro horário (8h30 às 10h30), homens e mulheres ficavam em lugares separados com uma programação específica para cada grupo. No segundo horário matinal (10h30 às $12 \mathrm{~h} 30)$, todos se encontravam. O outro culto acontecia à noite (19h30 às 21h30), totalizando dez cultos durante toda a programação, sendo as tardes livres. Em cada encontro, vários cantores e cantoras pertencentes à Central Gospel (gravadora de Malafaia) eram responsáveis pelo louvor (momento musical do culto), que era seguido de uma pregação, a conferência. Malafaia foi conferencista por duas vezes. Outros pastores de diferentes igrejas foram convidados (cada um ministrando uma conferência). Foram eles: Pr. Coty, presidente da ONG cristã Jovens com uma Missão, no Paraná; Pr. Marco Antônio, da igreja Comunidade Internacional da Zona Sul, no Rio de Janeiro; Pr. Silmar Coelho, da Igreja Viva, no Rio de Janeiro; Pr. Walmir Cohen, da igreja evangélica Fé para Todos, também do Rio de Janeiro.

12 Equipamento acoplado às câmeras de vídeo que exibe o texto a ser lido pelo apresentador.

Submetido em: $16 / 11 / 2020$ Aprovado em: 12/05/2021

\section{Cleonardo Mauricio Junior* (cleonardomj@gmail.com)}

* Pesquisador de Pós-Doutorado no Programa de Pós-Graduação em Antropologia da Universidade Federal de Pernambuco (PPGA/UFPE), Recife, PE, Brasil; Bolsista do Programa Nacional de Pós-Doutorado (PNPD-CAPES); Doutor em Antropologia pelo PPGA/UFPE. 


\section{Resumo:}

\section{O pastor como hiperconvertido: uma etnografia da constituição do líder pentecostal}

Neste artigo pretendo mostrar como se dá a constituição do pastor pentecostal. Entendendo a conversão como um processo contínuo no qual o fiel constrói uma narrativa específica de si mesmo, a constituição do pastor pentecostal pode ser considerada uma hiperconversão, na medida em que são os mestres dessa narrativa os reconhecidos como vocacionados para a carreira de pastor. Mostrarei ainda como as dimensões da linguagem, da materialidade e da experiência, organizadas normativamente pela ideologia semiótica pentecostal, estão entrelaçadas neste processo de hiperconversão. Para dar conta desse objetivo, baseio minha análise em pesquisa de campo com observação participante na Escola de Líderes da Associação Vitória em Cristo (Eslavec), realizada na cidade de Águas de Lindoia, em São Paulo. A Eslavec é conduzida pelo pastor Silas Malafaia, líder da Associação promotora do curso e pastor presidente da Assembleia de Deus Vitória em Cristo (Advec). Acompanhei ainda jovens recém-ordenados pastores e candidatos ao pastorado que haviam participado da Escola de Líderes, membros da Advec, como também jovens vocacionados de outras igrejas pentecostais no intuito de estender para o campo pentecostal em geral minhas generalizações sobre a transformação de si posta em prática pelos pentecostais e especialmente por aqueles que decidem seguir a carreira de pastor.

Palavras-chave: conversão, hiperconversão, ideologia da linguagem, ideologia semiótica, pastor pentecostal.

\section{Abstract:}

\section{The pastor as hyper converted: an ethnography of the constitution of the Pentecostal leader}

In this paper I intend to show the constitution of the Pentecostal pastor. Understanding conversion as a continuous process in which the faithful build a specific narrative of themselves, the constitution of the Pentecostal pastor can be considered a hyperconversion, insofar as the masters of this narrative are those recognized as called for the pastoral career. I will also show how the dimensions of language, materiality and experience, organized normatively by the Pentecostal semiotic ideology, are intertwined in this process of hyperconversion. To achieve this objective, I base my analysis on field research with participant observation at the School of Leaders of the Victory in Christ Association (ESLAVEC), held in the city of Águas de Lindoia, in São Paulo. ESLAVEC is led by pastor Silas Malafaia, leader of the Association 
promoting the event and pastor president of the Assembly of God Victory in Christ (ADVEC). I also followed young ordained pastors and candidates for pastorate who had participated in the School of Leaders, members of ADVEC, as well as young people from other Pentecostal churches in order to extend my generalizations about the transformation of themselves put into practice by Pentecostals and especially by those who decide to pursue a pastoral career over the Pentecostal field in general.

Keywords: conversion, hyperconversion, linguistic ideology, semiotic ideology, Pentecostal pastor.

Errata

Onde se lia:

Cleonardo Mauricio Junior

Leia-se:

Cleonardo Mauricio-Junior

Este trabalho está licenciado com uma Licença Creative Commons - Atribuição Não-Comercial 4.0 Internacional 